\title{
Urea distribution in renal failure
}

\author{
D. J. BLACKMORE, W. J. ELDER, AND C. H. BOWDEN \\ From the Research Department, R.A.F. Institute of Pathology and Tropical Medicine, and \\ the Renal Unit, Princess Mary's R.A.F. Hospital, Halton, Aylesbury, Bucks.
}

SYNOPSIS An assessment of intracellular urea removed during haemodialysis has been made from urea extraction and plasma urea estimations. An apparent wide variation in the movement of intracellular urea in patients with acute renal failure from obstetric and traumatic causes and with chronic renal failure is reported.

A method for the estimation of red cell water urea is presented. In two patients with chronic renal failure the red cell urea level was much higher than would have been expected from the plasma urea level before dialysis. In two obstetric patients there was no such discrepancy.

The conclusion is drawn that research should be directed to variations of intracellular metabolism in renal failure before a more rational approach can be made to its management.

Urea measurements made during haemodialysis of patients with renal failure have presented anomalies which are apparently inconsistent with the postulate that urea is freely diffusible throughout the total body water. In an earlier paper two of us analysed 60 haemodialyses with respect to the urea fall in plasma (Blackmore and Elder, 1961). A theoretical fall in plasma urea was calculated from the known urea clearance of the artificial kidney, the assumed total body water of the patient, and the initial plasma urea. The actual fall in plasma urea never significantly exceeded the calculated figure. In some patients with trauma or glomerulonephritis the fall in plasma urea was less than predicted, whereas in patients with renal failure complicating pregnancy the actual and calculated plasma urea falls were very close. The prediction of plasma urea fall from the theoretical performance of the artificial kidney was not a reliable procedure, partly because the machine did not necessarily perform as predicted and partly because the urea did not apparently travel from cells to extracellular fluid by a simple process of diffusion in all cases. As the ratio of calculated to observed plasma urea fall was found to correlate with the aetiology of the primary condition it was felt that variation in the performance of the machine was not a major factor. It was postulated that urea exists in both cell and plasma in diffusible and non-diffusible forms, and that there is a greater ratio of nondiffusible urea in the cell than in the plasma, these ratios being maintained in equilibrium. This ratio

Received for publication 23 January 1963. might be determined by the aetiology of the primary condition.

Shackman, Chisholm, Holden, and Pigott (1962) found in muscle biopsies an increased intracellular urea concentration in 14 of their 19 unselected patients and a decrease in the remaining five. They commented that this tended to support the concept that urea might exist as diffusible and non-diffusible moieties.

Further investigations on the dialyses of seven patients in renal failure are presented.

\section{MATERIAL}

The details of the patients investigated during dialysis are shown in Table I.

In our previous paper (Blackmore and Elder, 1961) the glomerulo-nephritic group included five patients with chronic renal failure due to glomerulonephritis. During the period of the present investigation no patient with glomerulonephritis was dialysed, but two patients (C.G. and W.W.) with chronic renal failure due to nephrosclerosis were included as it appeared from our previous studies that they behaved in a similar manner with respect to urea distribution. This group is not strictly comparable with that previously presented.

\section{METHODS}

Haemodialyses were performed with a Kolff disposable twin-coil unit using a modified Travenol artificial kidney. The coil was sealed in the can with sponge rubber and the bath circulating pump altered to give a constant flow of 34 litres per minute under variable load. The blood flow was measured by electromagnetic induction (Brennand 
TABLE I

SUMMARY OF PATIENTS

\begin{tabular}{|c|c|c|c|c|c|c|c|}
\hline & & Sex & Age & $\begin{array}{l}\text { Days of } \\
\text { Oliguria }\end{array}$ & $\begin{array}{l}\text { Maximum } \\
\text { Plasma Urea } \\
\text { (mg./100 ml.) }\end{array}$ & $\begin{array}{l}\text { Dialyses } \\
\text { (day from } \\
\text { onset of renal } \\
\text { failure) }\end{array}$ & Remarks \\
\hline $\begin{array}{l}\text { Obstetric } \\
\text { L.F. }\end{array}$ & $\begin{array}{l}\text { Septic abortion at about tenth } \\
\text { week of pregnancy }\end{array}$ & $\mathbf{F}$ & 31 & 20 & 470 & 8 and 15 & $\begin{array}{l}\text { Curettage of uterus under general } \\
\text { anaesthesia on third day. Progress } \\
\text { through oliguric and recovery phases } \\
\text { uneventful }\end{array}$ \\
\hline R.J.H. & $\begin{array}{l}\text { Toxaemia of pregnancy } \\
\text { Anterior rupture of membranes } \\
\text { at term, followed by spontaneous } \\
\text { delivery of live male child; } \\
\text { post-partum eclampsia }\end{array}$ & $\mathbf{F}$ & 22 & 16 & 410 & 7 and 14 & $\begin{array}{l}\text { Satisfactory involution of uterus. } \\
\text { 'Toxic psychosis' developed after first } \\
\text { dialysis, treated with thioridazine } \\
\text { (Melleril). Uneventful progress through } \\
\text { oliguric and recovery phases }\end{array}$ \\
\hline
\end{tabular}

Chronic Renal Failure

C.G. Nephrosclerosis with polyuria $\quad$ M $49 \quad 18 \quad 490 \quad 12,15$, Myocardial infarction and 18

Severely ill throughout, rapid rise of plasma urea and potassium. From 13th day required small amounts of metaraminol bitartrate (Aramine) to maintain the blood pressure. Died during fourth dialysis as a result of a further myocardia infarct. Post-mortem examination confirmed the diagnosis

W.W. Malignant hypertension, narrowed left renal artery, impaired renal function, left renal endarterectomy

$\begin{array}{lll}M & 38 & 27\end{array}$

27

Traumatic and right humerus; gross contusion of lower abdomen and thighs; perforated bladder and rectum
P.U. Ventricular septal defect; closure with hypothermia and bypass
A.J.M. Crush injury to right arm, followed by gas gangrene

$\begin{array}{lll}M & 19 & 20\end{array}$

20
470

\section{$8,12,17$, and 22}

Progress through oliguric phase only complicated by moderately severe exfoliative dermatitis (presumed drug sensitivity) for which prednisolone was given from the 13 th day. Hypotensive therapy started on 32nd day. Discharged on 44th day with blood urea $55 \mathrm{mg}$. $100 \mathrm{ml}$. and urine volumes 1.5 to 2.01 . 24 hours.

On first day general anaesthesia for insertion of Steinmann's pin into right tibia, suture of bladder, and transverse colostomy. General condition fair through oliguric and recovery phases. On 17th day general anaesthesia for application of hip spica and exploration and further suture of bladder laceration. Transferred to Surgical Division on 30 th day having made a good recovery

On fifth day sudden rise of blood pressure to c. $200 / 140 \mathrm{~mm}$. $\mathrm{Hg}$; this returned to normal levels within the next five days without treatment. In recovery phase developed right lower lobe pneumonia. Discharged on 23rd day with normal plasma urea, having made a good recovery

$9,11,13,16$, 18 , and 22

Acute renal failure followed profound blood pressure fall during massive debridement three days after crash injury. The next day the right arm was amputated. Very ill throughout oliguric and recovery phases. Tracheotomy performed on 7 th day. On 16th day passed massive melaena stools Died on 30th day from septicaemia and Bunker, 1960). Sodium and potassium concentrations in the dialysing fluid varied from patient to patient but no urea was added. The dialysing fluid was prepared from de-ionized water (conductivity $<20 \mu$ mho). Lactic acid was added to adjust the $p \mathrm{H}$ range to 7.4 to 7.6 ; to maintain this $p \mathrm{H}, 5 \% \mathrm{CO}_{2}$ in oxygen was bubbled through the dialysing fluid during the period of dialysis.

The urea concentration in the dialysing bath was estimated in duplicate by the method of Fawcett and Scott (1960). A modification of this method using a protein 
precipitation stage was used for the red cell and plasma urea estimations.

RED BLOOD CELL UREA CONCENTRATION To $2 \mathrm{ml}$. diluted whole blood (adjusted to give a final urea content of less than $1 \mathrm{mg}$. urea $/ 100 \mathrm{ml}$.) was added $2 \mathrm{ml}$. of buffered urease reagent. After 30 minutes' incubation at room temperature $0.5 \mathrm{ml} .2 / 3 \mathrm{~N}$ sulphuric acid and $0.6 \mathrm{ml}$. $10 \%$ sodium tungstate were added in this order. The slight excess of sodium tungstate produced more consistent results. The tubes were stood for 10 minutes and then centrifuged at 3,000 r.p.m. for 10 minutes.

To $2 \mathrm{ml}$. of the supernatant the following reagents were added in quick succession: $2 \mathrm{ml}$. of sodium phenate reagent, $3 \mathrm{ml}$. $0.01 \%$ sodium nitroprusside, and $3 \mathrm{ml}$. $0.02 \mathrm{~N}$ sodium hypochlorite. The colour was left to develop away from direct light for 60 minutes and then compared in a Hilger-Spekker colorimeter at $630 \mathrm{~m} \mu$ (Kodak filter no. 7) against standards and blanks similarly treated.

Plasma was obtained from heparinized blood (7.5 units heparin per ml. blood) separated within 10 minutes of sampling. The urea content was then estimated in the same manner.

The standard urea solution ( $1 \mathrm{mg}$. urea/100 ml.) was freshly prepared with low conductivity water $(<0 \cdot 1 \mu$ mho).

Each estimation was prepared in duplicate or quadruplicate; the standard and blank were estimated in quadruplicate.

A Seligson pipette was used for the initial aqueous dilutions of the blood and plasma. Automatic syringes were employed for the colour reagents. De-ionized water was used throughout (conductivity $<0.1 \mu$ mho).

Using this technique on 10 sera estimated in quadruplicate the standard deviation of difference for individual results from the quadruplicate means was $0.8 \mathrm{mg}$. urea/ $100 \mathrm{ml}$.

The test tubes used in this estimation were thoroughly washed in detergent and not submitted to chromic acid treatment. A difference was observed in precision if the latter was used (S.D. haemosol $\pm \mathbf{0 . 8} \mathrm{mg}$. urea $/ 100 \mathrm{ml}$.; S.D. chromic acid $\pm 2.7 \mathrm{mg}$. urea $/ 100 \mathrm{ml}$.).

The haematocrit values were determined in quadruplicate using calibrated Wintrobe tubes. These were spun for 60 minutes at 3,000 r.p.m. using an M.S.E. haematocrit centrifuge. From the whole blood urea, plasma urea, and packed cell volume the red cell urea may be simply calculated:

R.B.C. urea $=\left[\right.$ whole blood urea $-\left(\frac{100-\text { P.C.V. }}{100} \times\right.$

$$
\text { plasma urea) }] \times \frac{100}{\text { P.C.V. }}
$$

As the water content of the red cell is approximately $69 \%$ of its volume (Van Slyke, Wu, and McLean, 1923) the theoretical concentration of urea in the red cell water will be:

$$
\text { R.B.C. } \mathrm{H}_{2} \mathrm{O} \text { urea }=\frac{\text { red blood cell urea }}{0.69}
$$

provided that the urea is in fact all dissolved in red cell water.
The calculation of red cell water urea magnifies small errors in dermination of whole blood and plasma urea, espesially at low P.C.V. values. Thus the accuracy of the red cell water urea determination is much lower than that of plasma and whole blood ureas. For example, at a red cell water urea level of $350 \mathrm{mg} . / 100 \mathrm{ml}$., a change of less than $40 \mathrm{mg} . / 100 \mathrm{ml}$. is not significant as this is within the limits of maximum experimental error. Every precaution was taken to limit any inaccuracy but a difference of $1 \mathrm{mg}$. $/ 100 \mathrm{ml}$. on either the plasma or whole blood urea will affect the red cell water urea calculation by approximately $4 \mathrm{mg} . / 100 \mathrm{ml}$. at a P.C.V. of $40 \%$.

The method of Fawcett and Scott (1960) is claimed to have a high degree of specificity for the estimation of urea in plasma, and it is likely to have a similar specificity for urea in the red cell method described. Although this was not investigated extensively, it was found that no colour was produced from red cell extracts in the absence of urease indicating a lack of non-specific colourproducing substances.

CHANGES IN INTRACELLULAR UREA CONCENTRATION If the amount of urea extracted by haemodialysis is known it is possible to calculate the change in the urea concentration of the intracellular fluid from the body weight and the change in plasma urea concentration. In the absence of direct body fluid measurements on individual patients it was assumed that the extracellular fluid (ECF) was $15 \%$ of the total body weight, that the intracellular fluid (ICF) was $42 \%$ of the total body weight, and that the plasma water was $94 \%$ of the plasma volume (within normal protein concentrations). Although these approximations were not exact for each patient they have allowed assessment of gross changes. In addition, it was mecessary to assune that the plasma water urea concentration represented the ECF urea concentration. The change in the urea concentration of the intracellular fluid was calculated as follows:

$\begin{array}{ll}\text { Let ICF urea concentration } & =\mathrm{I}_{\mathrm{c}} \\ \text { Let ICF volume } & =\mathrm{I}_{\mathrm{v}} \\ \text { Let ECF urea concentration } & =\mathrm{E}_{\mathrm{c}} \\ \text { Let ECF volume } & =\mathrm{E}_{\mathrm{v}} \\ \text { Let plasma water urea concentration } & =\mathrm{P} \\ \text { Let urea extracted by haemodialysis } & =\mathrm{B}_{\mathrm{u}}\end{array}$
and $\triangle$ represents difference of concentration Then total body urea content $=$ ICF content + ECF$$
=\left(I_{c} \cdot I_{v}\right)+\left(E_{c} \cdot E_{v}\right)
$$$$
=\left(\mathbf{I}_{\mathrm{c}} \cdot \mathbf{I}_{\mathrm{v}}\right)+\left(\mathbf{P} \cdot \mathrm{E}_{\mathrm{v}}\right)
$$
content

If a quantity of urea is extracted by dialysis then:

$$
B_{u}=\text { ICF urea lost }+ \text { ECF urea lost ... }
$$
substituting (1) in (2)

$$
\begin{aligned}
\mathbf{B}_{\mathrm{u}} & =\left(\mathbf{I}_{\mathrm{v}} \cdot \triangle \mathbf{I}_{\mathbf{c}}\right)+\left(\mathrm{E}_{\mathrm{v}} \cdot \triangle \mathbf{P}\right) \\
\text { and } \triangle \mathbf{I}_{\mathrm{c}} & =\frac{\mathbf{B}_{\mathrm{u}}-\left(\mathrm{E}_{\mathrm{v}} \cdot \triangle \mathbf{P}\right)}{\mathbf{I}_{\mathbf{v}}}
\end{aligned}
$$

THEORETICAL DIALYSIS CURVE The nomogram of Blackmore and Elder (1961) was used to determine the expected plasma urea levels at two, four, and six hours. A theoretical dialysis curve was constructed from these figures. 
TABLE II

UREA DETERMINATIONS DURING DIALYSES

Dialysis Parameter ${ }^{1}$ Dialysis Time in Hours

No.

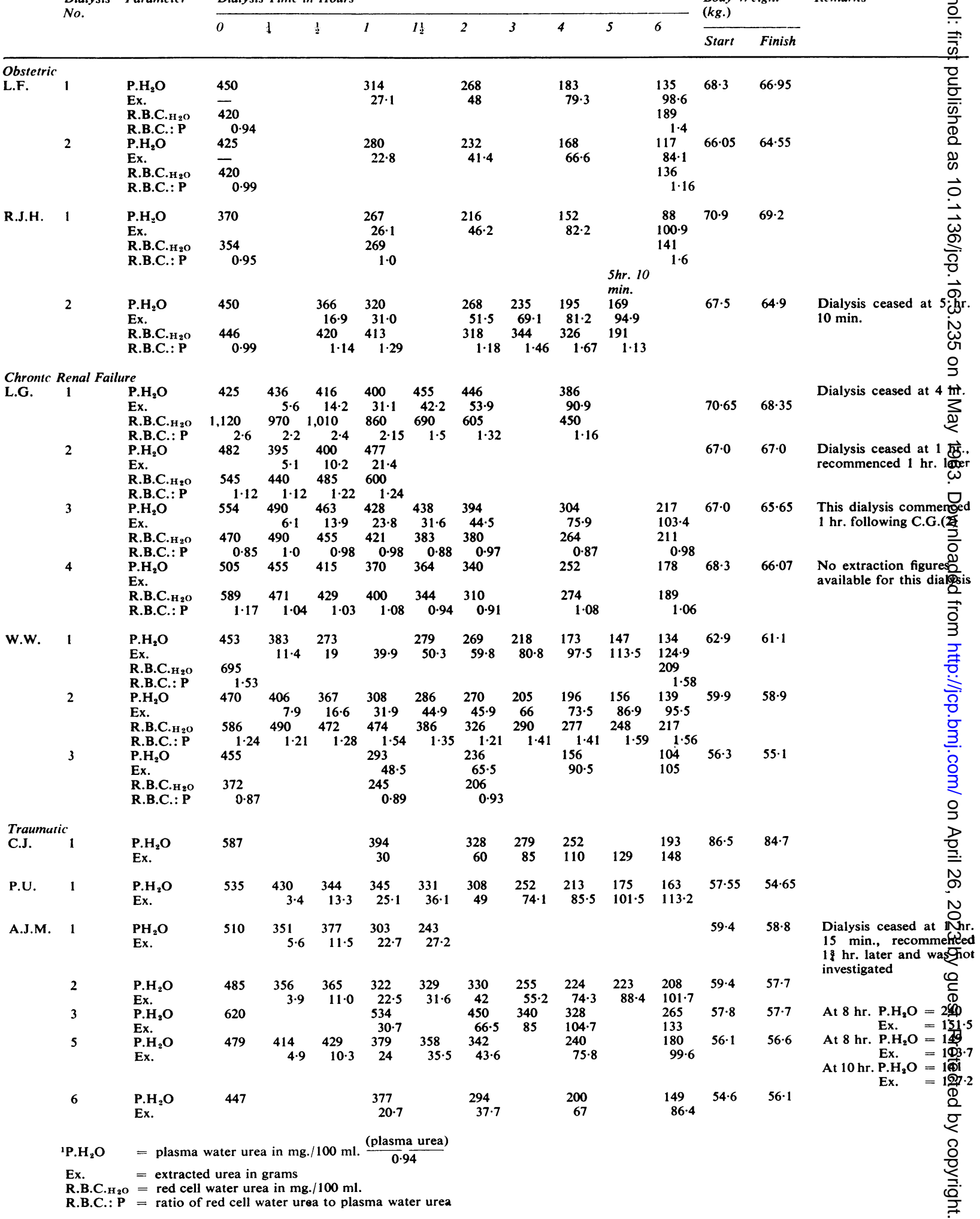

Body Weight

Remarks

( $k g$.

Start Finish 


\section{RESULTS}

In our earlier paper (Blackmore and Elder, 1961) it was suggested that the aetiology of the primary condition preceding renal failure might determine the proportion of bound urea within the cells. The current investigation supports this postulate and the results are therefore grouped according to aetiology. The characteristics of a group are apparent in the first dialysis of any patient, and the initial dialysis of one patient from each group is presented graphically. Data of all the patients are presented in the Tables.

The urea determinations are presented in Table II, while Table III shows the derived figures of falls in urea concentration in the extracellular and intracellular fluids during dialysis. Unfortunately no red cell water studies were made on the traumatic group of patients as a satisfactory method for this estimation had not been established at the time of their admission.

OBSTETRIC Figure 1 shows the theoretical dialysis figures, observed plasma, and red cell water urea concentrations plotted against time for the initial dialysis of patient R.J.H.

Throughout the dialysis the total urea extracted in the dialysing fluid was slightly less than that expected from the product of plasma water urea fall and calculated total body water. In all four dialyses examined in this group similar figures were observed.

Figure 2 shows the fall in plasma water urea expressed as extracellular fluid water urea, urea extracted in the dialysing fluid expressed as $\mathrm{mg}$./ $100 \mathrm{ml}$. total body water, and derived fall in intracellular fluid water urea in relation to time. It can be seen that throughout the dialysis the fall in the intracellular fluid urea was less than that of the extracellular fluid water urea. This could reasonably be explained by either a small time lag in intracellular to extracellular fluid urea diffusion, or an overestimation of total body water in all four dialyses. A time lag in intracellular to extracellular fluid urea diffusion could also explain the slight fall of plasma water urea to below the theoretical dialysis curve during the first hour (see Fig. 1), a drop that cannot be simply explained by the diluting effect of approximately 1 litre of priming blood. If, however, total

TABLE III

DERIVED FALLS IN EXTRACELLULAR AND INTRACELLULAR FLUID UREA CONCENTRATION DURING DIALYSES

No. of Extracellular Fluid Water Urea Drop ( $\mathrm{mg} . / 100 \mathrm{ml}$.)

Dialysis $\frac{\text { Dialysis Time in Hours }}{\text { Dim }}$

Intracellular Fluid Water Urea Drop (mg./100ml.)

Remarks

\begin{tabular}{lllllllll}
\hline $\mathrm{t}$ & $\frac{1}{2}$ & 1 & $1 \frac{1}{2}$ & 2 & 3 & 4 & 5 & 6
\end{tabular}

Dialysis Time in Hours

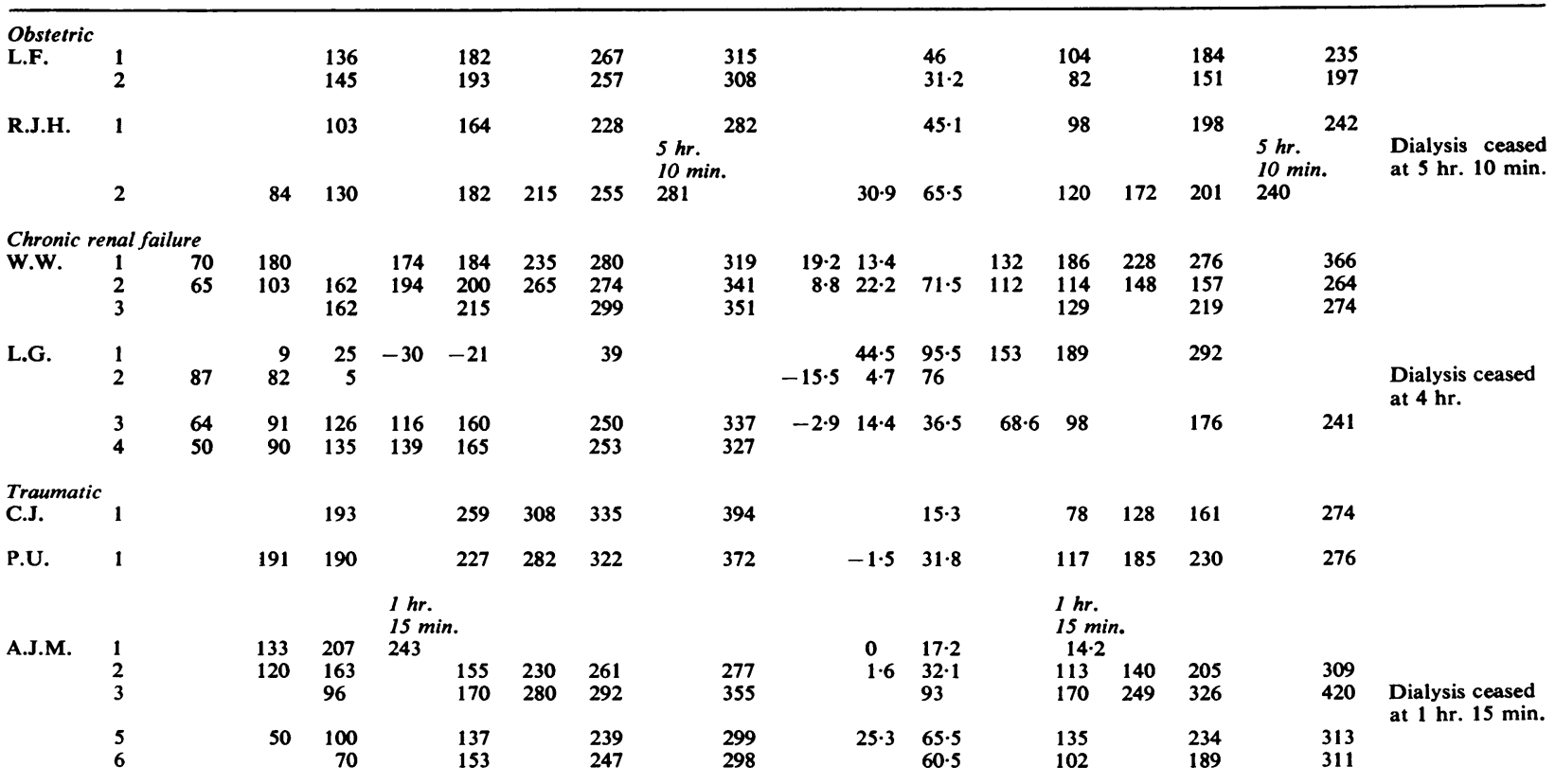

\begin{tabular}{lllllllll}
\hline & $\frac{1}{2}$ & 1 & $1 \frac{1}{2}$ & 2 & 3 & 4 & 5 & 6
\end{tabular}




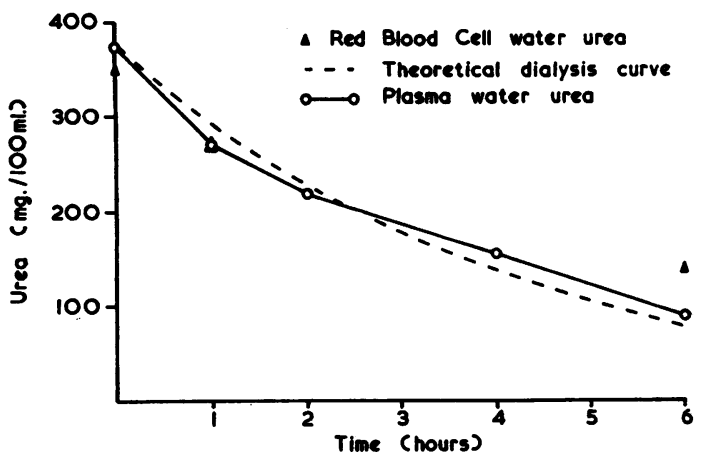

FIG. 1. First dialysis (R.J.H., obstetric) showing theoretical dialysis figures and observed plasma and red cell water urea concentrations plotted against time.

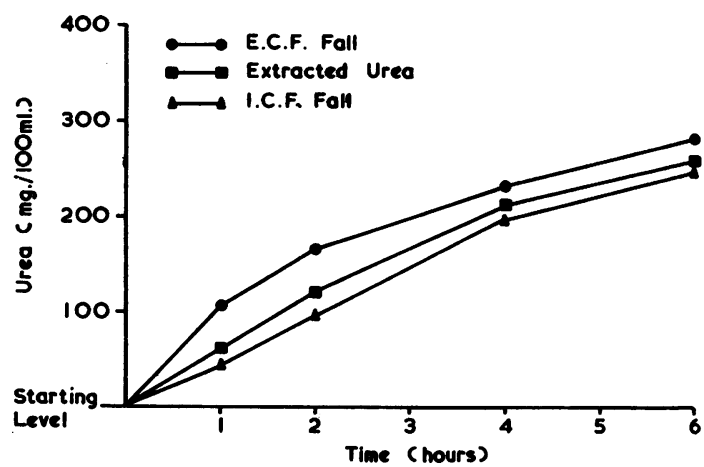

FIG. 2. First dialysis (R.J.H., obstetric) showing fall in plasma water urea expressed as extracellular fluid water urea, urea extracted in the dialysing fluid expressed as $\mathrm{mg} . / 100 \mathrm{ml}$. total body water, and the derived fall in intracellular fluid water urea in relation to time.

body water has been overstimated during these dialyses correction for this overestimation would make the curves on Fig. 2 for the extracellular and intracellular fluids and extracted urea more nearly coincide. There is no evidence of a greater amount of urea within the cells than could be expected from the plasma urea levels, and the results are consistent with urea being freely diffusible from the intracellular to extracellular fluids in these patients.

Blood studies at the beginning of dialysis showed a red cell water: plasma water urea ratio approximating to unity. At the end of the dialysis this ratio had increased. Subsequent dialyses produced similar results.

Chronic Renal fallure Figure 3 shows the theoretical dialysis figures, observed plasma, and red cell water urea concentrations plotted against time for the initial dialysis of patient L.G.
It can be seen that the levels of plasma urea diverged widely from the theoretical dialysis curve. At one and a half and two hours the concentration of urea in the plasma exceeded that at the beginning of dialysis. This suggested that during this period the rate of release of urea from the intracellular to

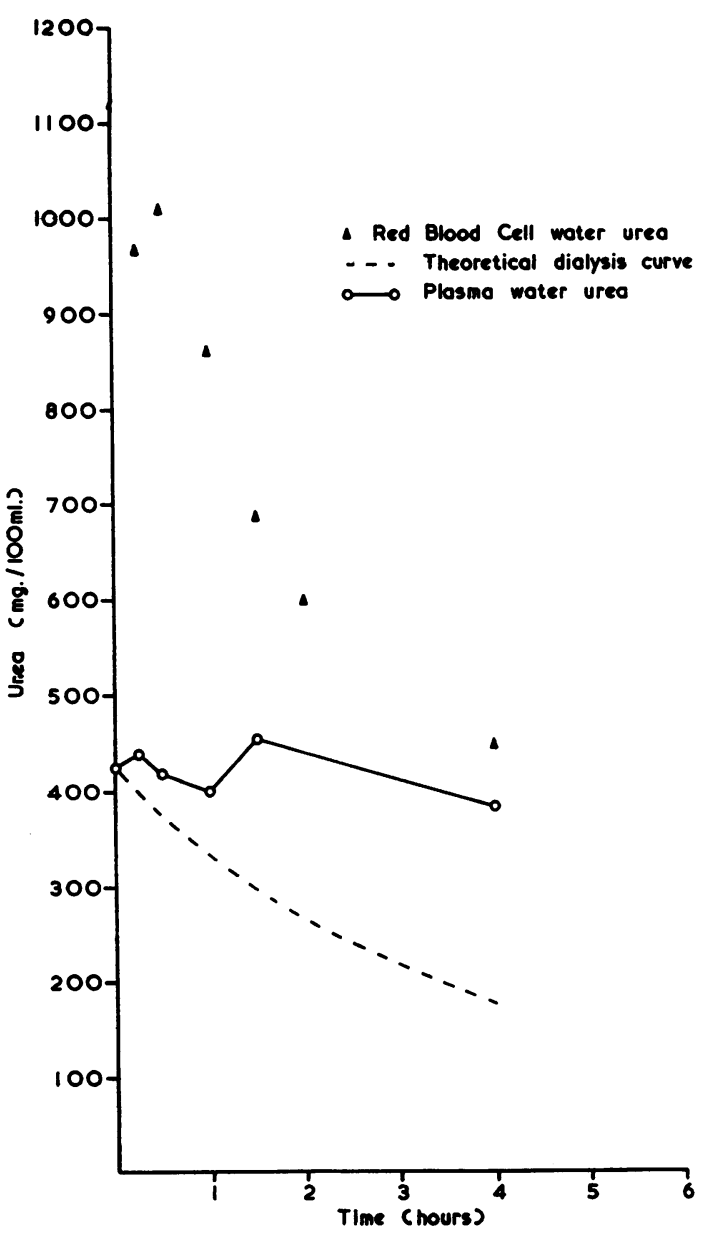

FIG. 3. First dialysis (L.G., chronic renal failure) showing theoretical dialysis figures and observed plasma and red cell water urea concentrations plotted against time.

extracellular fluid was greater than the rate of clearance from the artificial kidney coil.

Blood studies showed that the level of red cell water urea fell from $1,120 \mathrm{mg}$./ $100 \mathrm{ml}$. to $450 \mathrm{mg}$./ $100 \mathrm{ml}$. during the four-hour period of dialysis.

Figure 4 shows the fall in plasma water urea expressed as extracellular fluid water urea, urea extracted in the dialysing fluid expressed as mg./100 $\mathrm{ml}$. total body water, and the derived fall in intracellular fluid water urea related to time. 


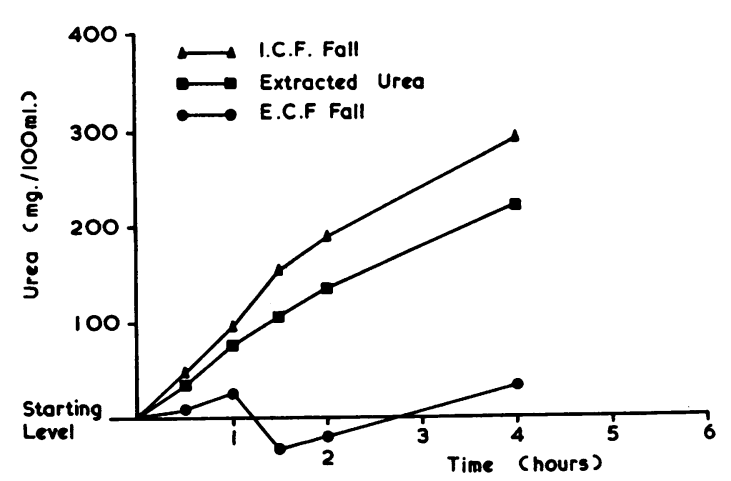

FIG. 4. First dialysis (L.G., chronic renal failure) showing fall in plasma water urea expressed as extracellular fluid water urea, urea extracted in the dialysing fluid expressed as $\mathrm{mg} . / 100 \mathrm{ml}$. total body water, and the derived fall in intracellular fluid water urea in relation to time.

In the first two dialyses of the patient investigated the early stages produced an extracellular fluid urea concentration that did not vary greatly from the starting level. This would indicate that at the beginning of dialysis the intracellular fluid urea concentration in this patient was considerably higher than that of the extracellular fluid and dialysis produced a rapid release of this urea from the intracellular fluid. Subsequent dialyses showed a gradual return to the obstetric pattern.

TRAUMATIC Figure 5 shows the theoretical dialysis figures, observed plasma, and red cell water urea concentrations plotted against time for the second dialysis of patient A.J.M. This patient has been presented graphically in preference to the others as he alone had a series of dialyses. The first dialysis was not fully investigated as a break of one and three quarter hours occurred after 75 minutes.

It can be seen that the level of plasma water urea fell below the theoretical curve during the initial stages of dialysis, crossed at one and a half hours, and then remained at a considerably higher level. The initial fall of plasma water urea greatly exceeded that calculated from dilution with 1 litre of priming blood. The extracted urea exceeded that calculated from the product of the plasma water urea drop and total body water. During the last two hours of dialysis the plasma water urea fell only $16 \mathrm{mg}$./ $/ 100 \mathrm{ml}$. but $28 \mathrm{~g}$. of urea was extracted within this period.

Figure 6 shows the fall in plasma water urea expressed as extracellular fluid water urea, urea extracted in the dialysing fluid expressed as mg./ $100 \mathrm{ml}$. total body water, and the derived fall in intracellular fluid water urea in relation to time.

It can be seen that during the first half hour of the dialysis the calculated intracellular fluid urea con-

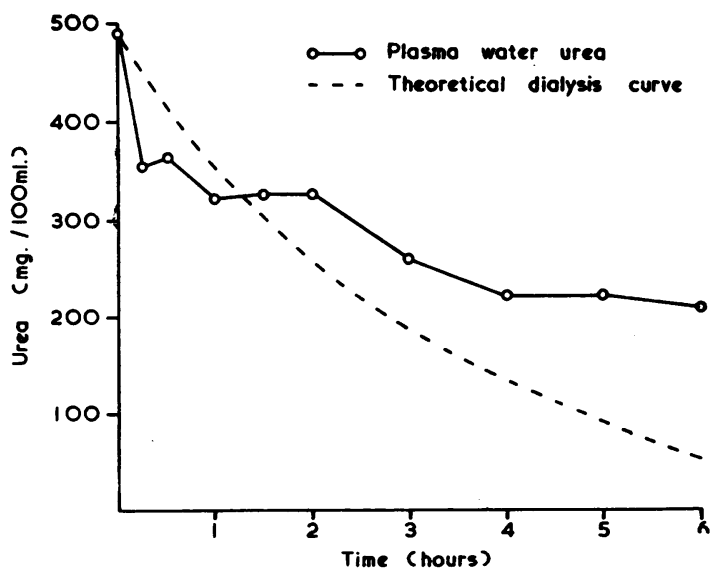

FIG. 5. Second dialysis (A.J.M., traumatic) showing theoretical dialysis figures and observed plasma and red cell water urea concentrations plotted against time.

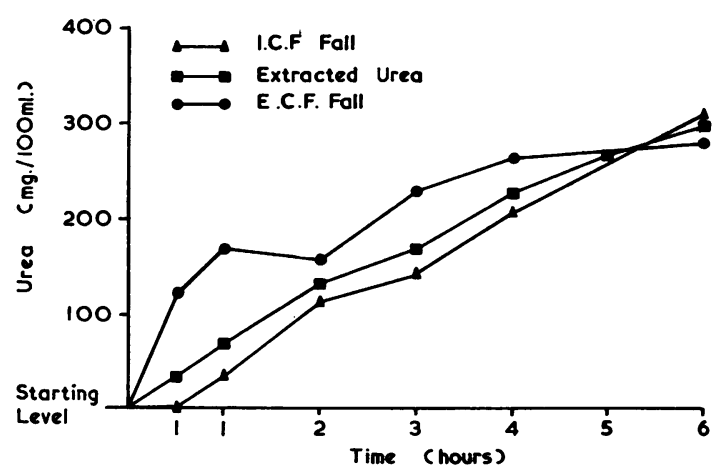

FIG. 6. Second dialysis (A.J.M., traumatic) showing fall in plasma water urea expressed as extracellular fluid water urea, urea extracted in the dialysing fluid expressed as $\mathrm{mg} .100 \mathrm{ml}$. total body water, and the derived fall in intracellular water urea in relation to time.

centration remained constant. This was observed in the first dialysis of all three injured patients studied. Following the static period it would appear that urea movement from intracellular to extracellular fluid began suddenly and was reflected by the flattening of the extracellular fluid urea curve. It is also evident that this sudden liberation of intracellular fluid urea was not of sufficient rapidity to cause the plasma water urea to rise significantly as was observed in chronic renal failure.

In subsequent dialyses the fall in plasma water urea progressively resembled the obstetric pattern but with a consistently higher urea extraction. It would therefore appear that this patient tended to maintain a higher concentration of intracellular fluid water urea than was apparent from plasma water urea studies during the entire period of 
TABLE IV

SUMMARY OF OBSERVED PATTERNS OF DIALYSIS

\begin{tabular}{|c|c|c|c|c|c|c|}
\hline \multirow[t]{2}{*}{ Group } & \multirow{2}{*}{$\begin{array}{l}\text { Dialysis } \\
\text { No. }\end{array}$} & \multirow{2}{*}{$\begin{array}{l}\text { Efficiency } \\
\text { Index }\end{array}$} & \multirow{2}{*}{$\begin{array}{l}\text { Pre-dialysis } \\
\text { Ratio of } \\
\text { Red Cell: } \\
\text { Plasma Urea }\end{array}$} & \multicolumn{3}{|c|}{ Intracellular Fluid Urea Drop ${ }^{1}$} \\
\hline & & & & $0-30 \mathrm{~min}$ & $30-60$ min. 60 & $60-120$ min. \\
\hline $\begin{array}{l}\text { Obstetric } \\
\text { ( } 2 \text { cases) }\end{array}$ & Any & Good & $\begin{array}{l}\text { Approxi- } \\
\text { mately unity }\end{array}$ & Slower & Same & Same \\
\hline \multirow[t]{2}{*}{$\begin{array}{l}\text { Chronic renal } \\
\text { failure ( } 2 \text { cases) }\end{array}$} & First & $\begin{array}{l}\text { Usually } \\
\text { very poor }\end{array}$ & $\begin{array}{l}\text { Usually } \\
\text { very high }\end{array}$ & Faster & $\begin{array}{l}\text { Much } \\
\text { faster }\end{array}$ & $\begin{array}{l}\text { Faster to } \\
\text { same }\end{array}$ \\
\hline & Subsequent & $\begin{array}{l}\text { Usually } \\
\text { improves }\end{array}$ & Decreases & & Approaches & obstetric pa \\
\hline \multirow[t]{2}{*}{$\begin{array}{l}\text { Traumatic } \\
\text { ( } 3 \text { cases) }\end{array}$} & First & $\begin{array}{l}\text { Usually } \\
\text { poor }\end{array}$ & $\begin{array}{l}\text { Figures not } \\
\text { available }\end{array}$ & Nil & $\begin{array}{l}\text { Nil to much } \\
\text { slower }\end{array}$ & Faster \\
\hline & Subsequent & Improves & $\begin{array}{l}\text { Figures not } \\
\text { available }\end{array}$ & & Approaches & obstetric pa \\
\hline
\end{tabular}

oliguria. In Table IV a summary of the trends in urea movement observed during dialysis are presented.

\section{DISCUSSION}

It was suggested by us (Blackmore and Elder, 1961) that urea exists in both diffusible and non-diffusible forms and that on dialysis the efficiency index ${ }^{1}$ would be affected by the ratio of these forms in cell and plasma.

It was also suggested that patients with renal failure of traumatic or glomerulonephritic origin would have an increase of non-diffusible cell urea before initial dialysis, whereas patients in renal failure of obstetric origin would behave as though urea were freely diffusible throughout the total body water.

In the two obstetric patients the extracted urea approximated that calculated from the product of the plasma urea fall and total body water suggesting that there were approximately equal concentrations of urea in the intracellular and extracellular fluids before dialysis. Red cell water studies have also indicated that there was no urea gradient between the red cell and the surrounding plasma. Dialvsis on these patients was therefore good when assessed in terms of plasma urea concentration and efficiency index.

'The efficiency index was calculated from the observed and theoretical plasma water urea levels after six hours of dialysis. The theoretical level was derived from the Blackmore and Elder nomogram. This nomogram was based on the clearance equation of Wolf, Remp, Kiley, and Currie (1951) from artificial kidney studies in vitro and the blood urea clearance figures of the Kolff twin coil artificial kidney (Elliott, Horn, Kerr, and Pearson, 1961).

$$
\text { Efficiency index }=\left[\frac{100 S U_{c}-U_{o} S}{U_{c}}\right]
$$

$U_{c}=$ calculated immediate post-dialysis plasma urea

$\mathrm{U}_{\mathrm{o}}=$ observed immediate post-dialysis urea

Efficiency expressed in this manner bears no relationship to the urea removed by dialysis.
In the three injured patients during the first part of dialysis the extracted urea approximated that calculated from the product of the plasma urea fall and the extracellular fluid volume. This suggests that there was a delay in movement of the intracellular fluid urea. During the latter part of the dialysis the extracted urea exceeded that calculated from the product of plasma urea fall and total body water, suggesting that the intracellular fluid urea was at a higher concentration than indicated by plasma urea estimations. If the initial delay period is short and the intracellular fluid urea at a high concentration moves early into the extracellular fluid then the efficiency, expressed in terms of plasma urea fall, will be poor although a large amount of urea is extracted. If, however, there is a prolonged delay in intracellular fluid urea clearance it is possible for the efficiency index to be good.

In the two patients with chronic renal failure the extracted urea greatly exceeded that calculated from the product of plasma urea fall and total body water throughout the whole period of dialysis. This suggests that they had a urea concentration in the intracellular fluid much greater than that of the extracellular fluid. The red cell water urea studies in this group demonstrated that such differences can exist in vivo but should not be interpreted as representing the general intracellular state. There appeared to be little delay in intracellular fluid clearance, resulting in an inefficient dialysis when assessed in terms of plasma urea clearance.

From the red cell urea studies it seems unlikely that all the red cell water urea is osmotically active. Patient L.G. had a red cell water urea level $600 \mathrm{mg}$./ $100 \mathrm{ml}$. higher than that in the plasma. If this was present in the cell water and available for dynamic 
equilibrium an osmotic gradient of $100 \mathrm{~m}$. osmols would have existed. A maintained osmotic gradient of this magnitude in circulating red blood cells would probably have caused distortion and lysis. No evidence of this process was found on blood smears or in plasma. Therefore it would appear that the urea was probably bound within the cell and became available for diffusion following clearance of the existing cell water urea. Assuming that the urea can be bound within the cell it is most likely that it is bound to the cellular proteins. Urea has been shown to combine with plasma albumin (Huggins, Tapley, and Jensen, 1951), heme (Burk and Greenberg, 1930), albumin and globulin (Pasynskii and Chernyak, 1950), haemoglobin and albumin (Murdaugh and Doyle, 1961), and sodium deoxyribonucleate (Ruffo, Santamaria, and Mattace-Raso, 1955).

The differences in intracellular urea binding observed within the groups probably result from variation in the intracellular metabolic states which can be corrected by dialysis. Theil, Brodine, and Doolan (1961) in a study on red blood cells have shown a significant decrease of glutathione content and diminished stability to acetylphenylhydrazine in patients with acute uraemia and a significant lowering of glutathione stability in patients with chronic renal disease when compared with 15 normal subjects. They also found that the red blood cell glucose-6-phosphate dehydrogenase activity was significantly greater in these patients.

The term 'efficiency index' was introduced during the previous analysis of 60 dialyses. It enabled a comparison to be made between the urea clearance characteristics in vitro of the artificial kidney and dialyses on patients. The results revealed the striking difference between patients in the various aetiological groups. Our further studies show that to measure the efficiency of a six-hour dialysis in terms of plasma urea fall can be misleading, due to the variation in intracellular urea levels and the time at which urea moves freely during the dialysis. It is now apparent that a more reasonable assessment of dialysis efficiency would be given by the quantity of urea removed by dialysis. As can be seen the urea extraction can increase considerably whilst the plasma urea remains relatively constant.

The optimum duration of dialysis with the Kolff twin coil artificial kidney has been generally accepted as six hours. By this time the patient is usually very tired, often exhausted, and longer dialysis has produced relatively little further change in plasma urea. Within this time electrolyte, water, and acid-base imbalance are generally corrected. We have dialysed patients for eight, 10, and $\mathbf{1 2}$ hours and have noted significant clinical improvement. In each instance at six hours the patient has been very tired and restless. As the dialyses were extended the patients became less tired, more alert and cooperative, and have appeared much improved in their general state. Table II shows the plasma and extracted urea figures during two prolonged dialyses (A.J.M. (3) and (5)). The extracted urea greatly exceeded that calculated from the plasma urea fall during the latter part of these dialyses suggesting that urea was still being removed from the intracellular fluid; this further emphasizes the need to assess the efficiency of dialysis in terms of urea extraction and not by plasma urea levels.

The present study suggests that the intracellular urea state is subject to wide variations which differ with aetiology. The plasma urea level does not give a reliable indication of the patient's state with respect to total body urea content, and the fall of plasma urea during dialysis is an unsatisfactory guide to the efficiency of dialysis.

We conclude that research should be directed to variations of intracellular metabolism in renal failure before a more rational approach can be made in its management.

We wish to thank Air Commodores W. P. Stamm and R. C. Jackson and Group Captain R. Mortimer for their help and encouragement. We are also very grateful to Dr. A. M. Joekes for his advice.

We have much appreciated the assistance of the staffs of the Renal Unit and the Biochemistry Department of the R.A.F. Institute of Pathology and Tropical Medicine, in particular Junior Technician A. E. McLachlan.

We wish to thank the Director General of Medical Services for permission to publish.

\section{REFERENCES}

Blackmore, D. J., and Elder, W. J. (1961). J. clin. Path., 14, 455. Brennand, R., and Bunker, N. V. (1960). Lancet, 1, 578.

Burk, N. F., and Greenberg, D. M. (1930). J. biol. Chem., 87, 197. Elliott, W., Horn, D. B., Kerr, D. N. S., and Pearson, D. T. (1961). Lancet, 1, 248.

Fawcett, J. K., and Scott, J. E. (1960). J. clin. Path., 13, 156.

Huggins, C., Tapley, D. F., and Jensen, E. V. (1951). Nature (Lond.), $167,592$.

Murdaugh, H. V. Jr., and Doyle, E. M. (1961). J. Lab. clin. Med, 57, 759.

Pasynskii, A. G., and Chernyak, R. S. (1950). Dokl. Acad. Nauk $S S S R, 73,771$.

Ruffo, A., Santamaria, R., and Mattace-Raso, F. (1955). Boll. Soc. Ital. Biol. sper., 31, 1381

Theil, G. B., Brodine, C. E., and Doolan, P. D. (1961). J. Lab. clin. Med., 58, 736.

Van Slyke, D. D., Wu, H., and McLean, F. C. (1923). J. biol. Chem., 56,765 .

Wolf, A. V., Remp, D. G., Kiley, J. E., and Currie, G. D. (1951). J. clin. Invest., 30, 1062.

Shackman, R., Chisholm, G. D., Holden, Angela J., and Pigott, R. W. (1962). Brit. Med. J., 2, 355. 
The above conversion factors have been rounded-off to facilitate conversion while retaining the degree of significance of the original results.

\section{NOMENCLATURE OF ISOENZYMES}

The discovery that a particular type of enzyme activity may apparently be associated with more than one protein and the diagnostic implications of this finding have resulted in an increasing number of references to these multiple molecular forms of enzymes (variously described as isoenzymes or isozymes) in the literature of chemical pathology. The lactate dehydrogenase (L.D.H.) activity of human tissues, for example, is made up of various proportions of five L.D.H. isoenzymes which are distinguishable by electrophoretic or other means.

In the absence of any officially agreed system of nomenclature, some degree of confusion has arisen in the numbering of these L.D.H. fractions; some workers designate the most rapidly anode-migrating isoenzyme L.D. 1 and the electrophoretically slowest L.D. 5 , while the reverse convention is followed in other publications. The Standing Committee on Enzymes of the International Union of Biochemistry is now attempting to formulate a standard nomenclature which, it is hoped, will shortly be published. Until its report is available, authors should state clearly which convention of isoenzyme numbering they are following.

References to the methods and units discussed can be found in King, E. J., and Campbell, D. M. (1961). Clin. chim. Acta, 6, 301. Report of Commission on Enzymes of International Union of Biochemistry (1961). Pergamon Press, Oxford.

The suggestions set out above for expressing enzymes in international units and on nomenclature for isoenzymes are recommended and approved by the Technical Methods Committee and the Committee on Chemical Pathology of the Association of Clinical Pathologists.

The late E. J. KING

D. W. MOSS

\section{CORRECTION}

In the Discussion in the paper 'Urea distribution in renal failure' by Blackmore et al. (J. clin. Path., 1963, 16,235 ) the formula on efficiency index in the footnote should read:-

$$
\text { Efficiency index }=100\left[\frac{\mathrm{U}_{\mathrm{c}}-\mathrm{U}_{0}}{\mathrm{U}_{\mathrm{c}}}\right]
$$

\section{Book reviews}

INTERNATIONAL REVIEW OF EXPERIMENTAL PATHOLOGY, Vol. I. Edited by G. W. Richter and M. A. Epstein. (Pp. $\mathrm{x}+$ 453; illustrated. 107s. 6d.) New York and

London: Academic Press. 1962.

Despite the current proliferation of scientific periodicals of all types, there has been a remarkable absence of any review, annual or otherwise, devoted to progress in pathology.

This serious deficiency has now been met by the Academic Press with an International Review of Experimental Pathology which is to appear annually. If the first volume is any guide, the series is likely to prove of the highest value. Volume I contains long articles on antibody production, arteriolar hyalinosis, the electron microscopy of damaged glomeruli, common cold viruses, radiationinduced bone disease, and cellular interactions in histogenesis. All these sections have been prepared with care by recognized authorities working actively in their field, and the standard is extremely high. The book is indeed worth reading from cover to cover and any comparisons between the authors seems uncalled for. The reviewer did, however, particularly enjoy the contributions of Nossal and Tyrrell on antibodies and coryzal viruses respectively. Some chapters, e.g., on electron microscopy, are based entirely on recent observations. In others, e.g., that on arteriolar hyalinosis, the discussion has its basis deep in the roots of pathology, in the controversies between Virchow and Rokitansky. It is this section by Pierre Dustin that reveals how heavily even an apparently well-defined morphological change relies upon experimentation to make it at all comprehensible. Almost everything that we understand, will understand, or think we understand in pathology is based on experimental observations.

The volume is well produced and is warmly recommended to all who have an interest in the study of disease. W. G. SPECTOR

DISEASES OF PORPHYRIN METABOLISM By A. Goldberg and

C. Rimington. (Pp. xvi +231 ; 38 figures; 19 plates. 82s. 6d.) Springfield, Illinois: Charles C. Thomas. 1962.

This volume makes a welcome addition to the American Lecture Series. The two authors are both recognized authorities on the subject from their special aspects and the combination of clinical and scientific data has been presented in a most interesting and informative way. The important recent advances which have been made both in the classification and in the biochemistry of the porphyrias makes the book particularly welcome at the present time.

The outlook is unusually wide since chapters are included on subjects such as the history, classification, and geographical distribution of porphyria, and also on experimental and natural porphyria in animals. For the clinician or biochemist the information given on the 